\title{
T-Lymphocytes and Disease Mechanisms in Wegener's Granulomatosis
}

\author{
Fan Hua Benjamin Wilde Sebastian Dolff Oliver Witzke \\ Department of Nephrology, University Duisburg-Essen, Essen, Germany
}

\section{Key Words}

Anti-neutrophil cytoplasmic antibodies $\cdot$ T-cells $\cdot$

Regulatory T-cells $\cdot$ Vasculitis $\cdot$ Wegener's granulomatosis

\begin{abstract}
The mechanisms underlying Wegener's granulomatosis (WG) are not well understood. The role of T-cells in the pathogenesis of WG has only recently come into focus of research. This review presents recent developments regarding the role of T-cells in WG. The occurrence of anti-neutrophil-cytoplasmic antibodies (ANCA) directed against proteinase-3 (PR-3) is a hallmark of WG. ANCA seem to mediate vasculitic damage in WG. Apart from ANCA, T-cells are involved in disease mechanisms. T-cells might participate in ANCA formation. Furthermore, T-cells are observed in affected tissue and granulomatous lesions. T-cells are indispensable for granuloma formation in other diseases and this might apply to WG too. In line with this, several aberrations of T-cell populations and alterations of the T-cell response were recently discovered in patients suffering from WG. Therefore, the impact of T-cell polarization, genotypic alterations modifying T-cell function and specific T-cell subsets on disease pathogenesis is discussed. Moreover, the influence of Staphylococcus aureus on T-cells and self-tolerance in WG is further elucidated. Finally, therapeutic options and implications with regard to T-cell-mediated pathogenesis are highlighted.

Copyright $\odot 2009$ S. Karger AG, Basel
\end{abstract}

\section{Introduction}

Wegener's granulomatosis (WG) is a granulomatousnecrotizing small vessel vasculitis [1]. WG forms together with microscopic polyangiitis (MPA) and Churg-Strauss syndrome (CSS), a disease complex named ANCA-associated vasculitis (AAV). All forms of AAV share common features like the presence of anti-neutrophil-cytoplasmic antibodies (ANCA). In WG, ANCA are usually directed against proteinase-3 (PR3) whereas patients with MPA and CSS have myeloperoxidase-specific ANCA. However, there are also cases reported in which ANCA were not detectable [2,3]. Although MPA and CSS show the same class of ANCA, the type of inflammation is different. Like WG, CSS is a granulomatous vasculitis whereas MPA is not. If and in what way this is related to the different types of ANCA is not clear. AAV is a life-threatening disease and adequate treatment is essential [4].

Both the innate and adaptive immune system play a role in disease mechanisms of WG, although the pathogenesis is not well understood [5]. Basically, it is believed that ANCA have a pathogenic role in disease mechanisms: the interaction of ANCA with its target antigen causes degranulation of neutrophils resulting in endothelial and finally vasculitic damage. There is evidence from in vivo experiments on the pathogenicity of MPOANCA [6]. Transfer of anti-MPO IgG in rodent models leads to necrotizing crescentic glomerulonephritis whereas administration of anti-PR3 IgG fails to induce granulomatous inflammation and glomerulonephritis [6-9]. Nevertheless, there is some evidence pointing at a patho-

PD Dr. Oliver Witzke

Department of Nephrology, University Duisburg-Essen

Hufelandstrasse 55

DE-45122 Essen (Germany)

Tel. +49 201723 3955, Fax +49 201723 3393,E-Mail oliver.witzke@ uk-essen.de 
Table 1. Overview on different T-cell subsets important in WG

\begin{tabular}{|c|c|c|c|}
\hline T-cell subset & Properties and phenotype & Function in WG & References \\
\hline $\begin{array}{l}\text { Naturally occurring } \\
\text { regulatory T-cells }\left(\mathrm{T}_{\text {reg }}\right)\end{array}$ & CD4+CD25 ${ }^{\text {bright }}$ FoxP3+CD127 low & $\begin{array}{l}\text { Presumably defective in function, } \\
\text { do not suppress sufficiently }\end{array}$ & Abdulahad et al. [49] \\
\hline $\begin{array}{l}\text { Induced regulatory } \\
\mathrm{T}_{\text {-cells }}\left(\mathrm{iT}_{\text {reg }} \text { ) }\right.\end{array}$ & $\begin{array}{l}\text { CD4+FoxP3-IL-10+ } \\
\text { CD4+FoxP3+TGF- } \beta\end{array}$ & $\begin{array}{l}\text { Not studied yet, mainly limit immune } \\
\text { responses in a physiologic context }\end{array}$ & $\begin{array}{l}\text { Piccirillo [51] } \\
\text { Roncarolo et al. [52] }\end{array}$ \\
\hline Naive T-cells & CD4+CD45RO-CD45RA+ & $\begin{array}{l}\text { Diminished in WG, skewing towards } \\
\text { memory phenotype }\end{array}$ & Marinaki et al. [55] \\
\hline Effector T-cells ( $\left.\mathrm{T}_{\text {eff }}\right)$ & & $\begin{array}{l}\text { Displaying effector function, e.g. IFN- } \gamma \\
\text { or TNF- } \alpha \text { production }\end{array}$ & \\
\hline $\begin{array}{l}\text { Effector memory T-cells } \\
\left(\mathrm{T}_{\mathrm{em}}\right)\end{array}$ & $\begin{array}{l}\mathrm{CD} 4+\mathrm{CD} 45 \mathrm{RO}+\mathrm{CCR} 7- \\
\mathrm{CD} 4+\mathrm{CD} 25+\mathrm{CD} 45 \mathrm{RO}+\mathrm{CD} 134+ \\
\mathrm{CD} 4+\mathrm{CD} 25+\mathrm{CD} 45 \mathrm{RO}+\mathrm{GITR}+\end{array}$ & $\begin{array}{l}\text { Expanded T-cell population, maybe driver } \\
\text { for granuloma formation and vasculitis }\end{array}$ & $\begin{array}{l}\text { Abdulahad et al. [23] } \\
\text { Wilde et al. [59] }\end{array}$ \\
\hline $\begin{array}{l}\text { Terminally differentiated } \\
\text { effector memory T-cells } \\
\left(\mathrm{T}_{\mathrm{tEM}}\right)\end{array}$ & CD4+CD45RO+CD28-CTLA4+ & $\begin{array}{l}\text { Abundantly present in granulomas, main } \\
\text { source of proinflammatory cytokines }\end{array}$ & $\begin{array}{l}\text { Lamprecht et al. } \\
{[25,26,64]} \\
\text { Hoff et al. }[96]\end{array}$ \\
\hline
\end{tabular}

genic role of PR3-ANCA in humans. For instance, several reports have shown an association of anti-PR3 titers and disease activity [10-12]. However, this could not be confirmed in a recent controlled trial conducted by Finkielman et al. [13] and thus remains controversial. The expression level of membrane-bound PR3 on neutrophils is reported to have impact on the relapse rate in WG [14]. Last but not least, B-cell-targeted therapy with rituximab seems to be efficacious in refractory disease and is accompanied by a decrease of autoantibody titer [15]. However, apart from autoantibodies and B-cells, T-cells play an important role in disease mechanism. The IgG subclass of ANCA indicates that a T-cell-dependent subclass switch has occurred [16]. In addition, granulomalike formations are usually found in affected tissue. These granulomas are a source of autoantibodies $[17,18]$. Granuloma formation is driven by T-cells and T-cell-derived cytokines $[19,20]$. T-cells are found in these lesions suggesting a role in the inflammatory process of WG [21]. Furthermore, Schmitt et al. [22] reported a strong correlation of disease activity and markers of T-cell activation such as soluble IL-2 receptor. T-cells are reported to be persistently expanded in WG [23]. Further evidence on the role of T-cells in AAV is provided by Ruth et al. [7] in an MPO animal model. Glomerular crescent formation was reduced after CD4+ T-cell depletion. These facts and the capacity of T-cells to control and induce immune responses gave rise to investigations of the role of T-cells in WG.

\section{Granuloma Formation and T-Cells in WG}

Fienberg [24] described WG-associated granulomas in detail. Macrophages, neutrophils and lymphocytes form granulomas usually observed in WG. Interestingly, most of the T-cells residing within granulomas display features of terminally differentiated effector memory T-cells $\left(\mathrm{T}_{\text {tEM }}\right)$ (table 1) [25-27]. $\mathrm{T}_{\mathrm{tEM}}$ show a downregulation of CD28 whereas the cytotoxic T-lymphocyte antigen-4 (CTLA-4) is overexpressed (table 1) [28]. Despite the regulatory functions of CTLA-4 in CD28-dependent T-cell activation, this molecule seems to confer protection against induced cell death by upregulation of anti-apoptotic BCL-2 as shown by Pandiyan et al. [29]. T-cells found in granulomas mainly show a Th1-cytokine pattern with secretion of IFN- $\gamma$ and TNF- $\alpha$ [30]. A recent report showed that PR3 antigen elicits strong Th1responses via dendritic cell maturation and subsequent antigen presentation to T-cells [31]. As granuloma formation is driven by Th1 responses, DC maturation and activation pathways might be important in disease pathogenesis. Intriguingly, PR3 antigen is usually present in granulomas and antigen-presenting cells (APC) are found in these lesions as well. Therefore, T-cells might be primed in granulomas. B-cells are also located in these lesions [17].

Thus, the question arises whether granulomas sustain the immune response in WG or even provide conditions favorable to overcome tolerance. 


\section{Genotypic Alterations in WG}

Genetic background is proven for some of the autoimmune diseases. Some findings point at a genetic disposition for WG as well. The coding gene for CTLA- 4 was studied extensively as this molecule plays a key role in the T-cell activation processes and shows an aberrant expression pattern in WG $[27,28]$. CTLA-4 is able to shut down and limit T-cell activation. It is expressed on T-cells and binds to CD80/CD86 on APC. Distinct polymorphisms of the CTLA-4 gene are associated with WG and correlate with the renal outcome of patients [32]. Some of the polymorphisms associated with WG were also shown to impair the regulatory function of CTLA-4 [33]. Dinucleotide expansions within the CTLA- 4 gene in WG might cause instability of mRNA and hence interfere with the expression as well as functionality of CTLA-4 [33-35].

A study on polymorphisms of the protein tyrosine phosphatase non-receptor type 22 (PTPN22) was published in 2005 [36]. PTPN22 is a tyrosine phosphatase that is involved in T-cell receptor signaling [37]. Jagiello et al. [36] revealed that a particular allele of the PTPN22 gene is a risk factor for WG. This specific allele is supposed to be less functional [36]. Enhanced proliferation of memory T-cells and formation of ectopic germinal centers in rodent animal models with complete deficiency of PTPN22 was demonstrated [38, 39]. Since similar phenomena such as memory T-cell expansion are observed in WG, a role for PTPN22 has to be considered [23].

Polymorphisms of genes coding for cytokines were studied in the past. Although TNF- $\alpha$ and IL-2 levels are usually increased in WG, no association with polymorphisms was found [40]. However, gene analysis for IL-10 revealed an increased frequency of a specific allele within the promoter region of IL-10 in WG [41]. This specific allele is associated with decreased production of the immunoregulatory cytokine IL-10 and thus might promote break of tolerance [42].

\section{Disease Pathogenesis and Specific T-Cell Subpopulations}

Regulatory T-cells $\left(\mathrm{T}_{\text {reg }}\right)$ and effector T-cells $\left(\mathrm{T}_{\text {eff }}\right)$ are major players in T-cell-mediated immunity (table 1). The role of both $\mathrm{T}_{\text {reg }}$ and $\mathrm{T}_{\text {eff }}$ in the pathogenesis of WG will be discussed below. $\mathrm{T}_{\text {reg }}$ and $\mathrm{T}_{\text {eff }}$ have different phenotypes and functions (table 1). $\mathrm{T}_{\text {reg }}$ control immune responses and limit inflammatory processes that are initiated and sustained by $\mathrm{T}_{\text {eff }}$. Thus, $\mathrm{T}_{\text {reg }}$ seem to have a key role in maintaining self-tolerance [43-47]. $\mathrm{T}_{\text {reg }}$ are usually found within the CD25+ T-cell population and express high levels of FoxP3 allowing differentiation from activated effector lymphocytes. $\mathrm{T}_{\text {reg }}$ depletion in animal models leads to autoimmunity and defective regulatory function was also seen in patients suffering from multiple sclerosis and rheumatoid arthritis. The role of $\mathrm{T}_{\text {reg }}$ has been investigated in WG. Marinaki et al. [48] assessed FoxP3 mRNA expression in T-cells from patients with AAV but did not find differences as compared with healthy controls. Abdulahad et al. [23] analyzed FoxP3 expression of effector memory T-cells $\left(\mathrm{T}_{\mathrm{em}}\right)$ defined as CD4+CD45RO+CCR7- in WG (table 1). It was shown that patients in remission have a slightly higher frequency of FoxP3 $+\mathrm{T}_{\mathrm{em}}$ accompanied by an increase of FoxP3$\mathrm{T}_{\mathrm{em}}$ than patients with active disease. Active patients did not show any differences in frequency of FoxP3 $+\mathrm{T}_{\mathrm{em}}$. Calculated ratios for FoxP3-/FoxP3+ T lymphocytes did not differ in comparison to healthy controls. Again, these findings did not point at a role for $\mathrm{T}_{\text {reg }}$ in the pathogenesis of WG. The latest report in this matter was published by Abdulahad et al. An increased frequency of $\mathrm{CD} 4+\mathrm{CD} 25^{\text {bright }} \mathrm{Fox} 3+$ and $\mathrm{CD} 4+\mathrm{CD} 45 \mathrm{RO}+\mathrm{CD} 25^{\text {bright }}$ FoxP3+ cells was detected in peripheral blood lacking correlation with clinical features. These $\mathrm{T}_{\text {reg }}$ were less efficient in inhibiting proliferation of responder T-cells than $\mathrm{T}_{\text {reg }}$ from $\mathrm{HC}$ [49]. The authors concluded that $\mathrm{T}_{\text {reg }}$ from WG patients are impaired in function. It has to be stressed that FoxP3 was recently reported to be transiently upregulated in activated lymphocytes [50]. Therefore, these findings need to be confirmed. Nevertheless, this is a first hint pointing at a role of $\mathrm{T}_{\text {reg }}$ in disease pathogenesis. A different subset of $\mathrm{T}_{\text {reg}}$, so-called 'induced regulatory T-cells' ( $\mathrm{iT}_{\text {reg }}$ ), have not been studied yet in WG but may be impaired in function, too (table 1) [51,52].

Apart from $\mathrm{T}_{\text {reg }}, \mathrm{T}_{\text {eff }}$ have been investigated as well. $\mathrm{T}_{\text {eff }}$ are controlled by $\mathrm{T}_{\text {reg }}$ and have the capacity to promote and initiate immune responses. In general, all T-cells displaying effector functions belong to $\mathrm{T}_{\text {eff }}$ [53]. Thus, $\mathrm{T}_{\mathrm{em}}$ and $\mathrm{T}_{\text {tEM }}$ are subsets of $\mathrm{T}_{\text {eff }}$ (table 1 ). It was shown earlier that the circulating $\mathrm{T}_{\text {tEM }}$ with no or little CD28 expression are expanded. $\mathrm{T}_{\text {tEM }}$ were also found in granulomas and are a major source of IFN- $\gamma$ and TNF- $\alpha$. The expansion is associated with disease progression and organ involvement $[25,30,54]$.

Recent reports show a significant increase of whole $\mathrm{T}_{\mathrm{em}}$ along with a decrease of naive T-cells in WG patients $[23,55]$. The cause for the expansion of $\mathrm{T}_{\mathrm{em}}$ has been investigated by several groups. Data from Czernok et al. [31] suggest a role for dendritic cells in initial stages of WG, 
but increased expression of CTLA- 4 followed by protection from induced cell death might contribute to $\mathrm{T}_{\mathrm{em}} \mathrm{ex}-$ pansion as well. Persistent antigen stimulation could also favor expansion of the $\mathrm{T}_{\mathrm{em}}$ compartment. A role for $\mathrm{T}_{\text {reg }}$ should be considered. Furthermore, differences between patients in remission and those with active disease were revealed. Patients in remission show higher levels of circulating $\mathrm{T}_{\mathrm{em}}$ than patients with active disease. It is speculated that these $T_{e m}$ migrate from peripheral blood to sites of inflammation causing a decrease in circulating $\mathrm{T}_{\mathrm{em}}$ during active disease [23, 31]. Memory T-cells also express receptors belonging to the tumor necrosis factor receptor (TNFR) superfamily (CD134 and glucorticoid-induced tumor-necrosis factor receptor, GITR); these receptors are known to confer resistance against immunoregulation [56-58]. In WG, CD134+/GITR+ T-cell subsets are expanded and associated with disease activity. These Tcell subsets are also present in inflamed tissue and might contribute to tissue damage in WG [59]. However, the importance of these T-cells as markers of disease activity needs further investigation. The pathogenic potential of these T-cells has to be elucidated further.

As $\mathrm{T}_{\mathrm{em}}$ and $\mathrm{T}_{\text {tem }}$ respond rapidly and establish a powerful immune response, they might account for relapsing disease course; a contribution to granuloma formation seems to be likely. New therapeutic options might arise from targeting these T-cells.

\section{T-Cell Cytokines and Chemokines in WG}

It is stated that there are differences in Th1/Th2 polarization depending on disease and disease stage [60-62]. Some authors support the idea that localized disease is associated with a Th1 response whereas a Th2 response is observed in systemic disease. Schonermack et al. [63] assessed sCD26 plasma levels as a marker for Th1 response in patients with localized and systemic WG. Levels were elevated in patients with localized disease suggesting a preferential Th1 response. Lamprecht et al. [64] compared CCR5 (Th1) and CCR3 (Th2) expression on T-cells from patients with WG. In localized disease, there was a higher expression of CCR5 as compared to CCR3 whereas both markers were expressed at equal levels in systemic disease. This was confirmed by observations made in biopsy studies. Muller et al. [65] characterized the cell infiltrates from nasal biopsies. These cells were mainly positive for CD26 and IFN- $\gamma$ in localized WG indicating a preferential Th1 response. In systemic disease, an increase of IL-4 mRNA was detected. Accordingly,
Balding et al. [60] found upregulation of IL-4 and failed to detect IFN- $\gamma$ in biopsies suggesting a Th2 response in systemic WG. In contrast to these studies, Csernok et al. [61] detected high levels of IFN- $\gamma$ mRNA and low levels IL-4 mRNA in granulomas in systemic WG. The majority of granuloma-derived T-cells were IFN- $\gamma$ producers. Hence, data on Th1/Th2 polarization is inconclusive.

TNF- $\alpha$ levels are also increased in WG [30]. T-cells found in granulomas and in the circulation are sources of TNF- $\alpha$ [30]. TNF- $\alpha$ acts as a proinflammatory cytokine on lymphocytes and neutrophils. It primes neutrophils, making them susceptible for ANCA-mediated degranulation and oxidative burst. Furthermore, it promotes upregulation of adhesion molecules on endothelial cells thus facilitating migration to the tissue. Thus, TNF$\alpha$ is of particular importance promoting vasculitic inflammation in several different ways.

IL-17-producing T-cells (Th17 cells) are major players in autoimmunity [66-68]. IL-17 is suggested to be involved in autoantibody formation as well as in recruitment and activation of neutrophils [69, 70]. Little data is available on the role of IL-17 in WG. However, a skewed Th17 response observed in WG might contribute to disease pathogenesis [71].

In conclusion, there is evidence for a disturbed cytokine axis promoting inflammation.

\section{Staphylococcus aureus-Induced Immune Alterations and WG}

Nasal carriage of S. aureus and the staphylococcal toxic shock syndrome toxin-1 (TSST-1) are risk factors for new onset and relapsing disease [72, 73]. Anti-S. aureus treatment with cotrimoxazole reduces the rate of relapses [74]. Therefore, the impact of $S$. aureus on pathogenesis in WG is discussed below. A study of outstanding interest was conducted by Pendergraft et al. [75], who investigated the role of complementary proteins in WG. In brief, the amino acid sequence of a specific protein is generally coded by the 'sense' strand of DNA [76]. Transcribing and translating this information results in a 'sense' protein. The opposite strand of the coding DNA is the so-called 'anti-sense' strand. The anti-sense strand carries genetic code of the complementary peptide that is the counterpart of the 'sense' protein [76]. Pendergraft et al. [75] hypothesize that the initial immune response in autoimmunity is directed against complementary PR3 (cPR3), resulting in the formation of antibodies against $\mathrm{CPR} 3$ (idiotypic response). Later on, an anti-idiotypic response 
against anti-cPR3 antibodies evolves. The antibodies formed during this anti-idiotypic response react to the sense autoantigen PR3. Indeed, Pendergraft et al. demonstrated the presence of anti-cPR3 antibodies in a minority of WG patients. These antibodies were specific for CPR3 and also bound specifically to anti-PR3. After having shown that anti-cPR3 and anti-PR3 antibodies from human WG sera form idiotypic pairs, mice were immunized with recombinant or synthetic human CPR3 in order to test the hypothesis in vivo. After immunization, anti-cPR3 as well as anti-PR3 antibodies were detected in mice supporting the idea of idiotypic and anti-idiotypic responses. Furthermore, Pendergraft et al. [75] searched for sources of cPR3 in WG patients. cPR3 transcripts were found in none of the healthy controls, ANCA-negative or lupus patients. However, cPR3 mRNA could be detected in leukocytes of PR3-ANCA patients. The origin of the cPR3 transcripts has not been unraveled so far. It could be of endogenous origin or exogenous origin, the latter introduced by pathogens. Indeed, genetic sequences complementary to human PR3 gene were detected in pathogens like S. aureus, Ross River virus and Entamoeba histolytica [75]. In conclusion, Pendergraft et al. provided substantial evidence for an involvement of cPR3 in disease mechanisms of WG; the idea is supported that microbial pathogens are of importance in different stages of autoimmunity.

Apart from classic ANCA, a different type reactive to lysosomal membrane protein-2 (LAMP-2) has been described by Kain et al. [77]. Anti-LAMP2 was present in WG patients with active disease and renal involvement; having entered remission, anti-LAMP2 was no longer detectable in the majority of patients. Kain et al. also provide evidence for in vitro and in vivo pathogenicity of anti-LAMP2. Anti-LAMP2 showed similar pathogenic potential in vitro as compared to anti-PR3. Shape change and degranulation of neutrophils was induced by antiLAMP2; in addition, apoptosis could be induced in human vascular endothelial cell culture by adding this antibody [77]. Furthermore, LAMP2 shows homology to the bacterial protein FimH, which is involved in adhesion to epithelial cells and is usually found on common bacterial pathogens such as Escherichia coli and Klebsiella pneumonia. Therefore, the in vivo pathogenicity of antiLAMP2 was tested in two different ways. First, anti-human rabbit IgG with specificity to LAMP2 were injected into Wistar-Kyoto (WKY) rats [77]. These rats developed focal necrotizing glomerulonephritis (FNGN). Thus, anti-LAMP2 antibodies seem to be pathogenic in vivo and promote FNGN. Then, in a second approach, WKY

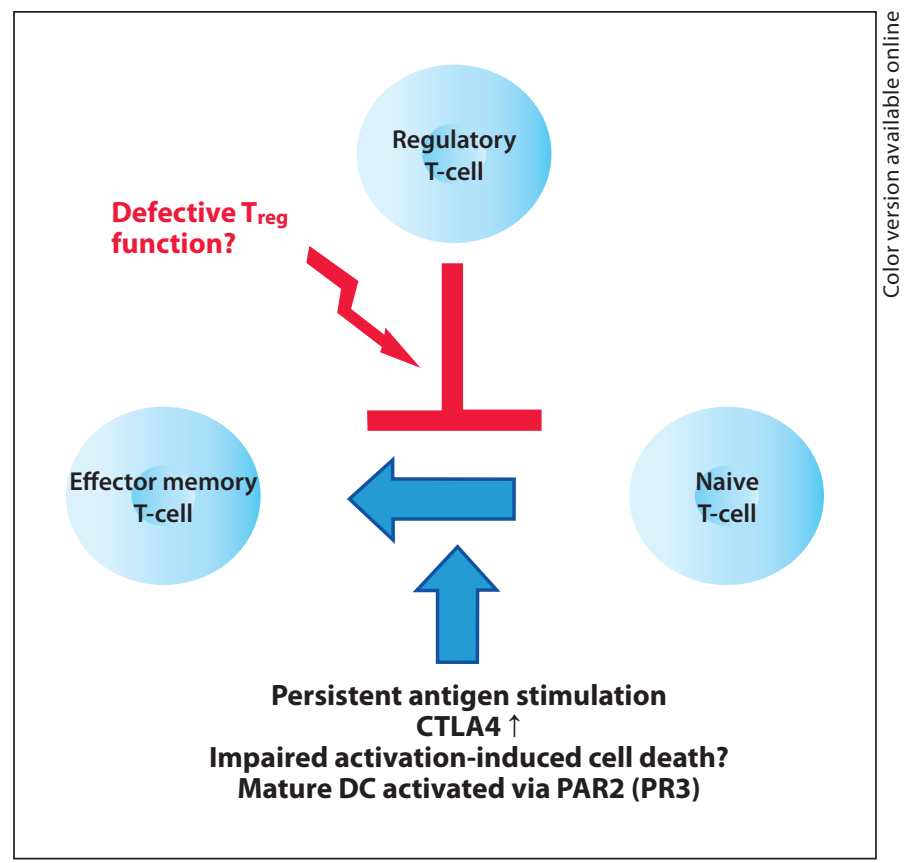

Fig. 1. The cause for the expansion of the memory T-cell compartment $\left(\mathrm{T}_{\mathrm{em}}\right.$ and $\left.\mathrm{T}_{\mathrm{tEM}}\right)$ is not known; however, there are some factors that might contribute to the persistent expansion of T-cells. $\mathrm{T}_{\text {reg }}$ defective in function might fail to limit $\mathrm{T}_{\mathrm{em}}$ expansion. In addition, persistent antigen stimulation might lead to ongoing activation and expansion of T-cells. Furthermore, CTLA- 4 is overexpressed on T-cells in WG followed by enhanced protection from activation induced cell death. Therefore, sustained activation and expansion of T-cells is favored in WG. Next to this, DCs might have a role in T-cell expansion. The autoantigen PR3 promotes maturation of DCs; these DCs are capable of stimulating and activating autoreactive T-cells. In conclusion, not a single but many different factors might cause persistent T-cell expansion in WG.

rats were immunized using recombinant FimH fusion protein. Subsequently, antibodies to FimH could be detected. However, standard ANCA assays were also positive. Antibodies to FimH cross-reacted with rat and human LAMP2. Furthermore, these rats developed FNGN and in some cases hemorrhagic pulmonary vasculitis occurred. Therefore, immunization with FimH induces antibodies to LAMP2 and provokes vasculitis. Finally, this study by Kain et al. [77] suggests that bacterial infections with common bacteria such as $E$. coli might trigger the development of autoantibodies and thus promote pauciimmune glomerulonephritis.

Exotoxins from S. aureus were suggested to be responsible for persistent activation and expansion of T-cells [78]. Some of the bacterial exotoxins are able to activate lymphocytes by binding to $\mathrm{V} \beta$ regions of the T-cell recep- 


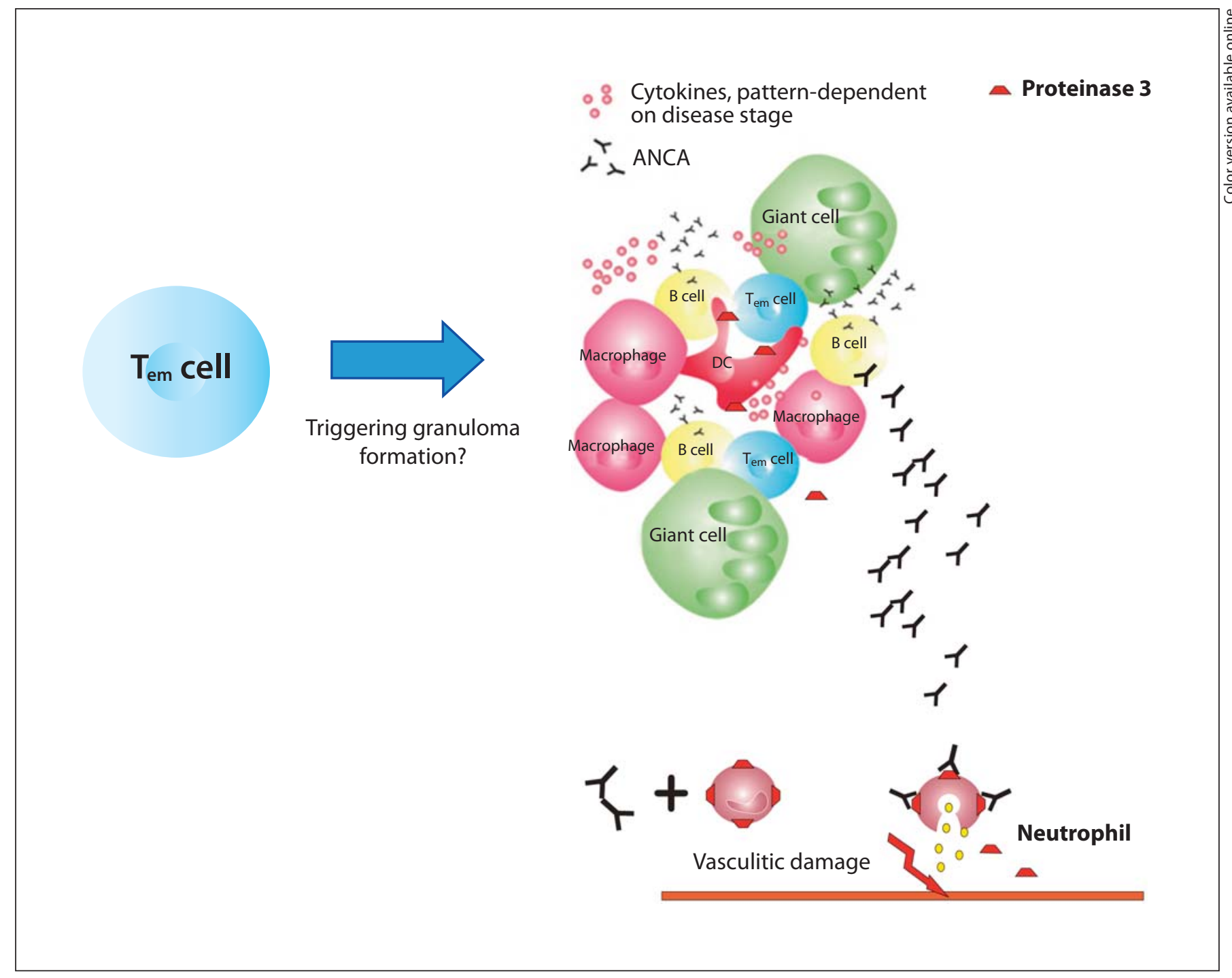

Fig. 2. $\mathrm{T}_{\mathrm{em}}$ trigger granuloma formation. Granulomas provide an inflammatory environment that sustains inflammation and might facilitate break of tolerance. Granulomas are sources for proinflammatory cytokines and autoantibodies; whether B- and/or T-cell maturation takes place is not fully proven. PR3 is also present in granulomas. PR3 acts on DCs and promotes maturation. Autoreactive T-cells might be activated by these DCs. ANCA produced by granuloma-resident B cells bind to primed neutrophils that express PR3 on their surface. Subsequently, degranulation of neutrophils is caused provoking vasculitic damage.

tor independent of antigen specificity; these exotoxins are so-called superantigens (SAg). SAg bind to MHC class II on APC and to T-cell receptor on T-cells outside the antigen-binding groove [79]. Especially expansion and activation of autoreactive T-cells could contribute to autoimmune disease. Popa et al. [78] analyzed the frequency of $\mathrm{V} \beta$-expressing T-cells. Although T-cell subsets expressing $V \beta$ regions with affinity to $S A g$ were expanded, no correlation with presence of SAg or S. aureus was seen.

\section{Therapeutic Implications}

There is a rationale for therapeutic lymphocyte depletion as T-cells contribute to disease mechanisms. For this purpose, anti-thymocyte globulin (ATG) was administered to patients with refractory disease in the context of clinical studies. At least partial remission could be induced, but in view of severe side effects also known from transplant studies, ATG treatment is not the first choice 
of therapy [80-82]. An antibody (alemtuzumab) directed against CD52 (displayed on mature lymphocytes) was also used for T-cell depletion in some small studies with patients suffering from WG. Responses and even sustained remissions were achieved in these patients. In line with the experience on ATG administration, alemtuzumab was used only in an experimental setting because of the risk for infections, malignancies and allergic reactions. No sufficient long-term data is available [83-86].

Targeting cytokines is a more specific therapeutic opportunity. Anti-TNF- $\alpha$ biologics were used abundantly in many different autoimmune diseases. It is also administered in WG in selected cases. There are different forms of anti-TNF- $\alpha$ biologics: (1) etanercept is a fusion protein with two TNF- $\alpha$ receptors bound to the Fc part of a human IgG; (2) infliximab is a chimeric monoclonal IgGantibody able to bind soluble and membrane-bound TNF- $\alpha$, and (3) adalimumab is a human monoclonal IgG antibody with two binding sites for soluble or already bound TNF- $\alpha$.

Etanercept was tested against a placebo in a large, controlled trial named WGET [87]. Either etanercept or the placebo was added to the standard therapy. In this trial, both arms were comparable with regard to induction of remission or relapse rate. Interestingly, the incidence of malignancies was higher in the etanercept arm [88]. Some small studies were conducted with infliximab; a total of 48 patients were included in these uncontrolled trials [89-92]. 38 patients received infliximab in addition to a standard treatment regimen. 33 of these 38 patients entered remission. However, a relapsing disease course was observed frequently. In one of these trials, 10 patients received sole infliximab treatment with corticosteroids; complete remission (5) and partial remission (5) were in- duced [89]. Right now, no data is available on adalimumab. The efficacy of anti-TNF- $\alpha$ agents in WG remains uncertain. Additional controlled clinical trials are needed to assess the potency and safety of anti-TNF- $\alpha$ agents in WG.

Attenuation of T-cell-dependent immune responses by blocking the CD28/CD80 pathway is effective in animal models. The CTLA-4Ig was tested recently in human clinical trials on rheumatoid arthritis (RA). So far, CTLA4Ig seems to be a promising therapeutic option for refractory disease in RA $[93,94]$. Even though disease pathogenesis is not comparable to WG, T-cell activation and CD80 expression pattern is altered in AAV [27]. Hence, modifying costimulatory pathways might be a new and effective therapeutic approach [95].

\section{Conclusion}

T-cells contribute to disease mechanisms in WG. Both the pathogenesis as well as the key events leading to the break of tolerance have not been uncovered yet. Potentially, $\mathrm{T}_{\text {reg }}$ are not able to control $\mathrm{T}_{\mathrm{em}}$ sufficiently. Thus, defective $\mathrm{T}_{\text {reg }}$ function, persistent antigen stimulation, protection from induced cell death and activated DCs might cause an expansion of $\mathrm{T}_{\mathrm{em}}$ (fig. 1). Hence, $\mathrm{T}_{\mathrm{em}}$ might be major players in disease mechanisms by promoting granuloma formation (fig. 2). Thereafter, granulomas provide a proper environment for a break of tolerance and sustained autoantibody as well as T-cell-mediated inflammation (fig. 2). Further efforts in unraveling the disease pathogenesis of WG will finally result in new and effective therapeutic strategies.

\section{References}

1 Bosch X, Guilabert A, Font J: Antineutrophil cytoplasmic antibodies. Lancet 2006;368: 404-418.

2 Eisenberger U, Fakhouri F, Vanhille P, Beaufils H, Mahr A, Guillevin L, et al: ANCAnegative pauci-immune renal vasculitis: histology and outcome. Nephrol Dial Transplant 2005;20:1392-1399.

-3 Reinhold-Keller E, de Groot K, Holl-Ulrich K, Arlt AC, Heller M, Feller AC, et al: Severe CNS manifestations as the clinical hallmark in generalized Wegener's granulomatosis consistently negative for antineutrophil cytoplasmic antibodies. A report of 3 cases and a review of the literature. Clin Exp Rheumatol 2001; 19:541-549.
4 Scott DGI, Watts RA: Systemic vasculitis: epidemiology, classification and environmental factors. Ann Rheum Dis 2000;59: 161-163.

5 Kallenberg CGM: Pathogenesis of PR3ANCA-associated vasculitis. J Autoimmun 2008;30:29-36.

-6 Xiao H, Heeringa P, Hu PQ, Liu Z, Zhao ML, Aratani Y, et al: Antineutrophil cytoplasmic autoantibodies specific for myeloperoxidase cause glomerulonephritis and vasculitis in mice. J Clin Invest 2002;110:955-963.
77 Ruth AJ, Kitching AR, Kwan RYQ, Odobasic D, Ooi JDK, Timoshanko JR, et al: Anti-neutrophil cytoplasmic antibodies and effector CD4+ cells play nonredundant roles in antimyeloperoxidase crescentic glomerulonephritis. J Am Soc Nephrol 2006;17:19401949.

8 Brouwer E, Huitema MG, Klok PA, de Weerd $\mathrm{H}$, Tervaert JW, Weening JJ, et al: Antimyeloperoxidase-associated proliferative glomerulonephritis: an animal model. J Exp Med 1993;177:905-914. 
-9 Pfister H, Ollert M, Frohlich LF, Quintanilla-Martinez L, Colby TV, Specks U, et al: Antineutrophil cytoplasmic autoantibodies against the murine homolog of proteinase 3 (Wegener autoantigen) are pathogenic in vivo. Blood 2004;104:1411-1418.

10 Segelmark M, Phillips BD, Hogan SL, Falk RJ, Jennette JC: Monitoring proteinase 3 antineutrophil cytoplasmic antibodies for detection of relapses in small vessel vasculitis. Clin Vaccine Immunol 2003;10:769-774.

-11 Cohen Tervaert JW, Huitema MG, Sluiter WJ, The TH, van der Hem GK, Kallenberg CGM, et al: Prevention of relapses in Wegener's granulomatosis by treatment based on antineutrophil cytoplasmic antibody titre. Lancet 1990;336:709-711.

12 Boomsma MM, Stegeman CA, van der Leij MJ, Oost W, Hermans J, Kallenberg CGM, et al: Prediction of relapses in Wegener's granulomatosis by measurement of antineutrophil cytoplasmic antibody levels - a prospective study. Arthritis Rheum 2000;43:2025-2033.

- 13 Finkielman JD, Merkel PA, Schroeder D, Hoffman GS, Spiera R, St. Clair EW, et al: Antiproteinase-3 antineutrophil cytoplasmic antibodies and disease activity in Wegener granulomatosis. Ann Intern Med 2007; 147:611-619.

14 Rarok AA, Stegeman CA, Limburg PC, Kallenberg CGM: Neutrophil membrane expression of proteinase 3 (PR3) is related to relapse in PR3-ANCA-associated vasculitis. J Am Soc Nephrol 2002;13:2232-2238.

$\checkmark 15$ Taylor SRJ, Salama AD, Joshi L, Pusey CD, Lightman SL: Rituximab is effective in the treatment of refractory ophthalmic Wegener's granulomatosis. Arthritis Rheum 2009; 60:1540-1547.

16 Brouwer E, Tervaert JWC, Horst G, Huitema MG, Vandergiessen M, Limburg PC, et al: Predominance of IgG1 and IgG4 subclasses of antineutrophil cytoplasmic autoantibodies in patients with Wegener's granulomatosis and clinically related disorders. Clin Exp Immunol 1991;83:379-386.

17 Voswinkel J, Muller A, Lamprecht P: Is PR3ANCA formation initiated in Wegener's granulomatosis lesions? Granulomas as potential lymphoid tissue maintaining autoantibody production. Ann NY Acad Sci 2005; 1051:12-19.

18 Voswinkel J, Mueller A, Kraemer JA, Lamprecht P, Herlyn K, Holl-Ulrich K, et al: Blymphocyte maturation in Wegener's granulomatosis: a comparative analysis of $\mathrm{VH}$ genes from endonasal lesions. Ann Rheum Dis 2006;65:859-864.

19 Co DO, Hogan LH, Il-Kim S, Sandor M: T cell contributions to the different phases of granuloma formation. Immunol Lett 2004; 92:135-142.

20 Sato IY, Kobayashi K, Yamagata N, Shikama Y, Kasama T, Kasahara K, et al: Modulation of granuloma formation in vitro by endogenous mediators. Immunopharmacology 1991;21:73-82.
21 Aries PM, Lamprecht P, Gross WL: Wegener's granulomatosis: a view from the granulomatous side of the disease. Isr Med Assoc J 2005;7:768-773.

22 Schmitt WH, Heesen C, Csernok E, Rautmann A, Gross WL: Elevated serum levels of soluble interleukin-2 receptor in patients with Wegener's granulomatosis. Association with disease activity. Arthritis Rheum 1992; 35:1088-1096.

23 Abdulahad WH, van der Geld YM, Stegeman CA, Kallenberg CG: Persistent expansion of CD4+ effector memory $\mathrm{T}$ cells in Wegener's granulomatosis. Kidney Int 2006;70: 938-947.

24 Fienberg R: A morphologic and immunohistologic study of the evolution of the necrotizing palisading granuloma of pathergic (Wegener's) granulomatosis. Semin Respir Med 1989;10:126-132.

25 Lamprecht P, Moosig F, Csernok E, Seitzer U, Schnabel A, Mueller A, et al: CD28 negative $\mathrm{T}$ cells are enriched in granulomatous lesions of the respiratory tract in Wegener's granulomatosis. Thorax 2001;56:751-757.

26 Lamprecht P, Mueller A, Gross WL: CD28$\mathrm{T}$ cells display features of effector memory $\mathrm{T}$ cells in Wegener's granulomatosis. Kidney Int 2004;65:1113-1114.

27 Moosig F, Csernok E, Wang G, Gross WL: Costimulatory molecules in Wegener's granulomatosis: lack of expression of CD28 and preferential up-regulation of its ligands B7-1 (CD80) and B7-2 (CD86) on T cells. Clin Exp Immunol 1998;114:113-118.

28 Steiner K, Moosig F, Csernok E, Selleng K, Gross WL, Fleischer B, et al: Increased expression of CTLA-4 (CD152) by T and $\mathrm{B}$ lymphocytes in Wegener's granulomatosis. Clin Exp Immunol 2001;126:143-150.

29 Pandiyan P, Gartner D, Soezeri O, Radbruch A, Schulze-Osthoff K, Brunner-Weinzier MC: CD152 (CTLA-4) determines the unequal resistance of Th1 and Th2 cells against activation-induced cell death by a mechanism requiring $\mathrm{PI}_{3}$ kinase function. J Exp Med 2004;199:831-842.

30 Komocsi A, Lamprecht P, Csernok E, Mueller A, Holl-Ulrich K, Seitzer U, et al: Peripheral blood and granuloma CD4+CD28- T cells are a major source of interferon- $\gamma$ and tumor necrosis factor- $\alpha$ in Wegener's granulomatosis. Am J Pathol 2002;160:1717-1724.

- 31 Csernok E, Ai M, Gross WL, Wicklein D, Petersen A, Lindner B, et al: Wegener autoantigen induces maturation of dendritic cells and licenses them for Th1 priming via the protease-activated receptor-2 pathway. Blood 2006; 107:4440-4448.

32 Spriewald BM, Witzke O, Wassmuth R, Wenzel RR, Arnold ML, Philipp T, et al: Distinct tumour necrosis factor- $\alpha$, interferon- $\gamma$ interleukin-10, and cytotoxic T-cell antigen 4 gene polymorphisms in disease occurrence and end-stage renal disease in Wegener's granulomatosis. Ann Rheum Dis 2005;64: 457-461.
33 Zhou YH, Huang DR, Paris PL, Sauter CS, Prock KA, Hoffman GS: An analysis of CTLA-4 and proinflammatory cytokine genes in Wegener's granulomatosis. Arthritis Rheum 2004;50:2645-2650.

34 Huang DR, Giscombe R, Zhou YH, Pirskanen R, Lefvert AK: Dinucleotide repeat expansion in the CTLA-4 gene leads to T cell hyperreactivity via the CD28 pathway in myasthenia gravis. J Neuroimmunol 2000; 105:69-77.

- 35 Ueda H, Howson JMM, Esposito L, Heward J, Snook H, Chamberlain G, et al: Association of the T-cell regulatory gene CTLA4 with susceptibility to autoimmune disease. Nature 2003;423:506-511.

- 36 Jagiello P, Aries P, Arning L, Wagenleiter SEN, Csernok E, Hellmich B, et al: The PTPN22 620W allele is a risk factor for Wegener's granulomatosis. Arthritis Rheum 2005;52:4039-4043.

37 Mustelin T, Alonso A, Bottini N, Huynh H, Rahmouni S, Nika K, et al: Protein tyrosine phosphatases in T-cell physiology. Mol Immunol 2004;41:687-700.

38 Luzina IG, Atamas SP, Storrer CE, daSilva LC, Kelsoe G, Papadimitriou JC, et al: Spontaneous formation of germinal centers in autoimmune mice. J Leukoc Biol 2001;70:578584.

39 Hasegawa K, Martin F, Huang GM, Tumas D, Diehl L, Chan AC: PEST domain-enriched tyrosine phosphatase (PEP) regulation of effector/memory $\mathrm{T}$ cells. Science 2004;303:685-689.

40 Huang D, Giscombe R, Zhou YH, Lefvert K: Polymorphisms in CTLA-4 but not tumor necrosis factor- $\alpha$ or interleukin- $1 \beta$ genes are associated with Wegener's granulomatosis. J Rheumatol 2000;27:397-401.

41 Murakozy G, Gaede KI, Ruprecht B, Gutzeit O, Schurmann M, Schnabel A, et al: Gene polymorphisms of immunoregulatory cytokines and angiotensin-converting enzyme in Wegener's granulomatosis. J Mol Med 2001;79:665-670

-42 Turner DM, Williams DM, Sankaran D, Lazarus M, Sinnott PJ, Hutchinson IV: An investigation of polymorphism in the interleukin-10 gene promoter. Eur J Immunogenet 1997;24:1-8.

-43 Scheffold A, Hühn J, Höfer T: Regulation of CD4+CD25+ regulatory $\mathrm{T}$ cell activity: it takes (IL-)two to tango. Eur J Immunol 2005; 35:1336

44 Wraith DC, Nicolson KS, Whitely NT: Regulatory CD4+ T cells and the control of autoimmune disease. Curr Opin Immunol 2004; 16:695.

45 Chai JG, Xue SA, Coe D, Addey C, Bartok I: Regulatory $\mathrm{T}$ cells, derived from naive CD4+CD25- T cells by in vitro FoxP3 gene transfer, can induce transplantation tolerance. Transplantation 2005;79:1310. 
46 Fontenot JD, Rudensky AY: A well-adapted regulatory contrivance: regulatory $\mathrm{T}$-cell development and the forkhead family transcription factor FoxP3. Nat Immunol 2005;6: 331.

-47 Wildin RS, Ramsdell F, Peake J, Faravelli F, Casanova JL: X-linked neonatal diabetes mellitus, enteropathy and endocrinopathy syndrome is the human equivalent of mouse scurfy. Nat Genet 2001;27:18.

-48 Marinaki S, Neumann I, Kalsch AI, Grimminger P, Breedijk A, Birck R, et al: Abnormalities of CD4 T-cell subpopulations in ANCA-associated vasculitis. Clin Exp Immunol 2005;140:181-191.

-49 Abdulahad WH, Stegeman CA, van der Geld YM, Doornbos-van der Meer B, Limburg PC, Kallenberg CG: Functional defect of circulating regulatory $\mathrm{CD} 4+\mathrm{T}$ cells in patients with Wegener's granulomatosis in remission. Arthritis Rheum 2007;56:2080-2091.

-50 Ziegler SF: FoxP3: not just for regulatory T cells anymore. Eur J Immunol 2007;37:2123.

51 Piccirillo CA: Regulatory T cells in health and disease. Cytokine 2008;43:395-401.

-52 Roncarolo MG, Gregori S, Battaglia M, Bacchetta R, Fleischhauer K, Levings MK: Interleukin-10-secreting type 1 regulatory $\mathrm{T}$ cells in rodents and humans. Immunol Rev 2006; 212:28-50.

-53 Appay V, van Lier RAW, Sallusto F, Roederer M: Phenotype and function of human T lymphocyte subsets: consensus and issues. Cytometry A 2008;73A:975-983.

54 Vogt S, Iking-Konert C, Hug F, Andrassy K, Hansch GM: Shortening of telomeres: Evidence for replicative senescence of T cells derived from patients with Wegener's granulomatosis. Kidney Int 2003;63:2144-2151.

-55 Marinaki S, Kalsch AI, Grimminger P, Breedijk A, Birck R, Schmitt WH, et al: Persistent T-cell activation and clinical correlations in patients with ANCA-associated systemic vasculitis. Nephrol Dial Transplant 2006;21:1825-1832.

-56 Huddleston CA, Weinberg AD, Parker DC: OX40 (CD134) engagement drives differentiation of CD4+ T cells to effector cells. Eur Immunol 2006;36:1093-1103.

-57 Lathrop SK, Huddleston CA, Dullforce PA, Montfort MJ, Weinberg AD, Parker DC: A signal through OX40 (CD134) allows anergic, autoreactive $T$ cells to acquire effector cell functions. J Immunol 2004;172:67356743.

>58 Valzasina B, Guiducci C, Dislich H, Killeen $\mathrm{N}$, Weinberg AD, Colombo MP: Triggering of OX40 (CD134) on CD4+CD25+ T cells blocks their inhibitory activity: a novel regulatory role for OX40 and its comparison with GITR. Blood 2005;105:2845-2851.
59 Wilde B, Dolff S, Cai X, Specker C, Becker J, Totsch M, et al: CD4+CD25+ T-cell populations expressing CD134 and GITR are associated with disease activity in patients with Wegener's granulomatosis. Nephrol Dial Transplant 2009;24:161-171.

60 Balding CEJ, Howie AJ, Drake-Lee AB, Savage COS: Th2 dominance in nasal mucosa in patients with Wegener's granulomatosis. Clin Exp Immunol 2001;125:332-339.

61 Csernok E, Trabandt A, Muller A, Wang GCC, Moosig F, Paulsen J, et al: Cytokine profiles in Wegener's granulomatosis - predominance of type 1 (Th1) in the granulomatous inflammation. Arthritis Rheum 1999;42:742-750.

62 Sanders JS, Stegeman CA, Kallenberg CG: The Th1 and Th2 paradigm in ANCA-associated vasculitis. Kidney Blood Press Res 2003;26:215-220.

63 Schonermarck U, Csernok E, Trabandt A, Hansen H, Gross WL: Circulating cytokines and soluble CD23, CD26 and CD30 in ANCA-associated vasculitides. Clin Exp Rheumatol 2000;18:457-463.

64 Lamprecht P, Bruhl H, Erdmann A, Holl-Ulrich K, Csernok E, Seitzer U, et al: Differences in CCR5 expression on peripheral blood CD4+CD28- T cells and in granulomatous lesions between localized and generalized Wegener's granulomatosis. Clin Immunol 2003;108:1-7.

65 Muller A, Trabandt A, Gloeckner-Hofmann K, Seitzer U, Csernok E, Schonermarck U, et al: Localized Wegener's granulomatosis: predominance of CD26 and IFN- $\gamma$ expression. J Pathol 2000;192:113-120.

66 Kurts C: Th17 cells: a third subset of CD4+ T effector cells involved in organ-specific autoimmunity. Nephrol Dial Transplant 2008; 23:816-819.

67 Korn T, Oukka M, Kuchroo V, Bettelli E Th17 cells: effector $\mathrm{T}$ cells with inflammatory properties. Semin Immunol 2007;19: 362-371.

68 Bettelli E, Oukka M, Kuchroo VK: Th-17 cells in the circle of immunity and autoim munity. Nat Immunol 2007;8:345-350.

69 Hsu HC, Yang P, Wang J, Wu Q, Myers R, Chen J, et al: Interleukin-17-producing $\mathrm{T}$ helper cells and interleukin-17 orchestrate autoreactive germinal center development in autoimmune BXD2 mice. Nat Immunol 2008;9:166-175.

70 Hoshino H, Laan M, Sjöstrand M, Lötvall J, Skoogh B-E, Lindén A: Increased elastase and myeloperoxidase activity associated with neutrophil recruitment by IL-17 in airways in vivo. J Allergy Clin Immunol 2000; 105:143-149.

71 Abdulahad WH, Stegeman CA, Limburg PC, Kallenberg CG: Skewed distribution of Th17 lymphocytes in patients with Wegener's granulomatosis in remission. Arthritis Rheum 2008;58:2196-2205.
72 Popa ER, Stegeman CA, Abdulahad WH, van der Meer B, Arends J, Manson WM, et al: Staphylococcal toxic shock syndrome toxin1 as a risk factor for disease relapse in Wegener's granulomatosis. Rheumatology 2007;46: 1029-1033

73 Stegeman CA, Tervaert JWC, Sluiter WJ, Manson WL, de Jong PE, Kallenberg CGM: Association of chronic nasal carriage of Staphylococcus aureus and higher relapse rates in Wegener granulomatosis. Ann Intern Med 1994;120:12-17.

74 Stegeman CA, Cohen Tervaert JW, de Jong PE, Kallenberg CGM, The Dutch Co-trimoxazole Wegener Study G: Trimethoprimsulfamethoxazole (co-trimoxazole) for the prevention of relapses of Wegener's granulomatosis. N Engl J Med 1996;335:16-20.

$>75$ Pendergraft WF, Preston GA, Shah RR, Tropsha A, Carter CW, Jennette JC, et al: Autoimmunity is triggered by cPR-3(105-201), a protein complementary to human autoantigen proteinase-3. Nat Med 2004;10:72-79.

76 McGuire KL, Holmes DS: Role of complementary proteins in autoimmunity: an old idea re-emerges with new twists. Trends Immunol 2005;26:367-372.

77 Kain R, Exner M, Brandes R, Ziebermayr R, Cunningham D, Alderson CA, et al: Molecular mimicry in pauci-immune focal necrotizing glomerulonephritis. Nat Med 2008;14: 1088-1096.

78 Popa ER, Stegeman CA, Bos NA, Kallenberg CGM, Tervaert JWC: Staphylococcal superantigens and T-cell expansions in Wegener's granulomatosis. Clin Exp Immunol 2003; 132:496-504.

79 Müller-Alouf H, Carnoy C, Simonet M, Alouf JE: Superantigen bacterial toxins: state of the art. Toxicon 2001;39:1691-1701.

80 Schmitt WH, Hagen EC, Neumann I, Nowack R, Flores-Suarez LF, van der Woude FJ: Treatment of refractory Wegener's granulomatosis with anti-thymocyte globulin: An open study in 15 patients. Kidney Int 2004; 65:1440-1448.

81 Hagen EC, Dekeizer RJW, Andrassy K, Vanboven WPL, Bruijn JA, Vanes LA, et al: Compassionate treatment of Wegener's granulomatosis with rabbit anti-thymocyte globulin. Clin Nephrol 1995;43:351-359.

-82 Tarkowski A, Anderssongare B, Aurell M: Use of anti-thymocyte globulin in the management of refractory systemic autoimmune diseases. Scand J Rheumatol 1993;22:261266.

83 Wertheim MS, Ross AH, Tole DM: The use of Campath in severe peripheral ulcerative keratitis associated with Wegener's granulomatosis. Eye 2006;20:1453-1454.

84 Lockwood CM: Refractory Wegener's granulomatosis: a model for shorter immunotherapy of autoimmune diseases. J R Coll Physicians Lond 1998;32:473-478. 
-85 Lockwood CM, Thiru S, Isaacs JD, Hale G, Waldmann H: Long-term remission of intractable systemic vasculitis with monoclonal-antibody therapy. Lancet 1993;341: 1620-1622.

>86 Mathieson PW, Cobbold SP, Hale G, Clark MR, Oliveira DBG, Lockwood CM, et al: Monoclonal-antibody therapy in systemic vasculitis. N Engl J Med 1990;323:250-254.

-87 Stone JH, Hoffman GS, Holbrook JT, Meinert CL, Dodge J, Donithan J, et al: Etanercept plus standard therapy for Wegener's granulomatosis. N Engl J Med 2005;352:351-361.

-88 Stone JH, Holbrook JT, Marriott MA, Tibbs AK, Sejismundo LP, Min YI, et al: Solid malignancies among patients in the Wegener's granulomatosis etanercept trial. Arthritis Rheum 2006;54:1608-1618.
89 Bartolucci P, Ramanoelina J, Cohen P, Mahr A, Godmer P, Le Hello C, et al: Efficacy of the anti-TNF- $\alpha$ antibody infliximab against refractory systemic vasculitides: an open pilot study on 10 patients. Rheumatology 2002;41: 1126-1132.

90 Lamprecht P, Voswinkel J, Lilienthal T, Nolle B, Heller M, Gross WL, et al: Effectiveness of TNF- $\alpha$ blockade with infliximab in re fractory Wegener's granulomatosis. Rheumatology 2002;41:1303-1307.

91 Huugen D, Tervaert JWC, Heeringa P: TNF$\alpha$ bioactivity-inhibiting therapy in ANCAassociated vasculitis: clinical and experimental considerations. Clin J Am Soc Nephrol 2006;1:1100-1107.

92 Booth A, Harper L, Hammad T, Bacon P, Griffith M, Levy J, et al: Prospective study of TNF- $\alpha$ blockade with infliximab in antineutrophil cytoplasmic antibody-associated systemic vasculitis. J Am Soc Nephrol 2004; 15:717-721.
93 Vincenti F, Luggen M: T-cell costimulation: a rational target in the therapeutic armamentarium for autoimmune diseases and transplantation. Annu Rev Med 2007;58: 347-358.

94 Cunnane G, Chan OTM, Cassafer G, Brindis S, Kaufman E, Yen TSB, et al: Prevention of renal damage in murine lupus nephritis by CTLA-4Ig and cyclophosphamide. Arthritis Rheum 2004;50:1539-1548.

$>95$ Levine SM, Stone JH: New approaches to treatment in systemic vasculitis: biological therapies. Best Pract Res Clin Rheumatol 2001;15:315-333.

-96 Hoff H, Knieke K, Cabail Z, Hirseland H, Vratsanos G, Burmester GR, et al: Surface CD152 (CTLA-4) expression and signaling dictates longevity of CD28null T cells. J Immunol 2009; 182:5342-5351. 